\title{
MataAksara
}

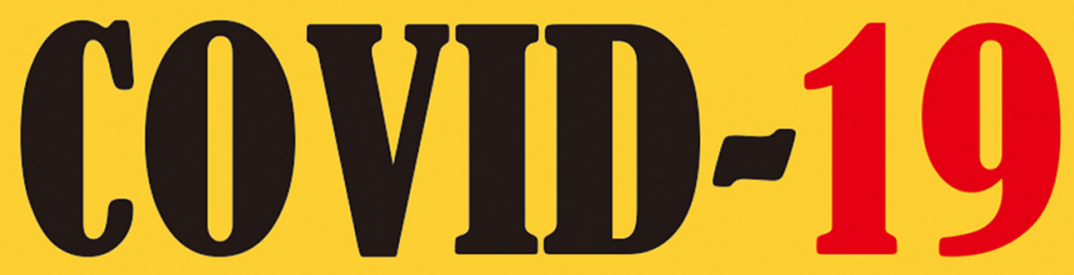

\section{THE NIGHTMARE OR RAINBOW}

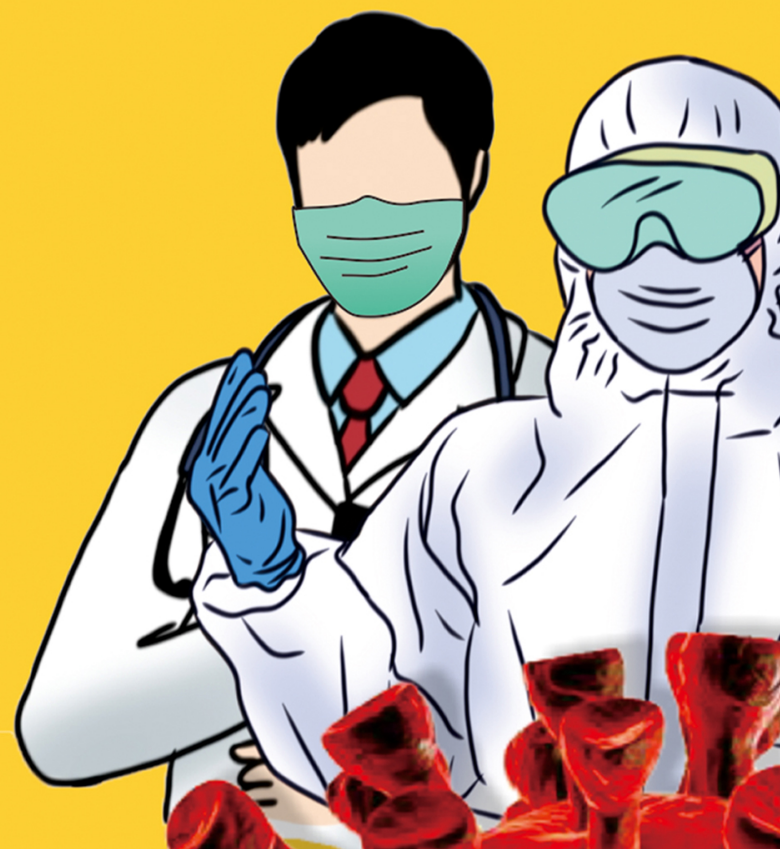

\section{SITI RAHAYU, DKK}



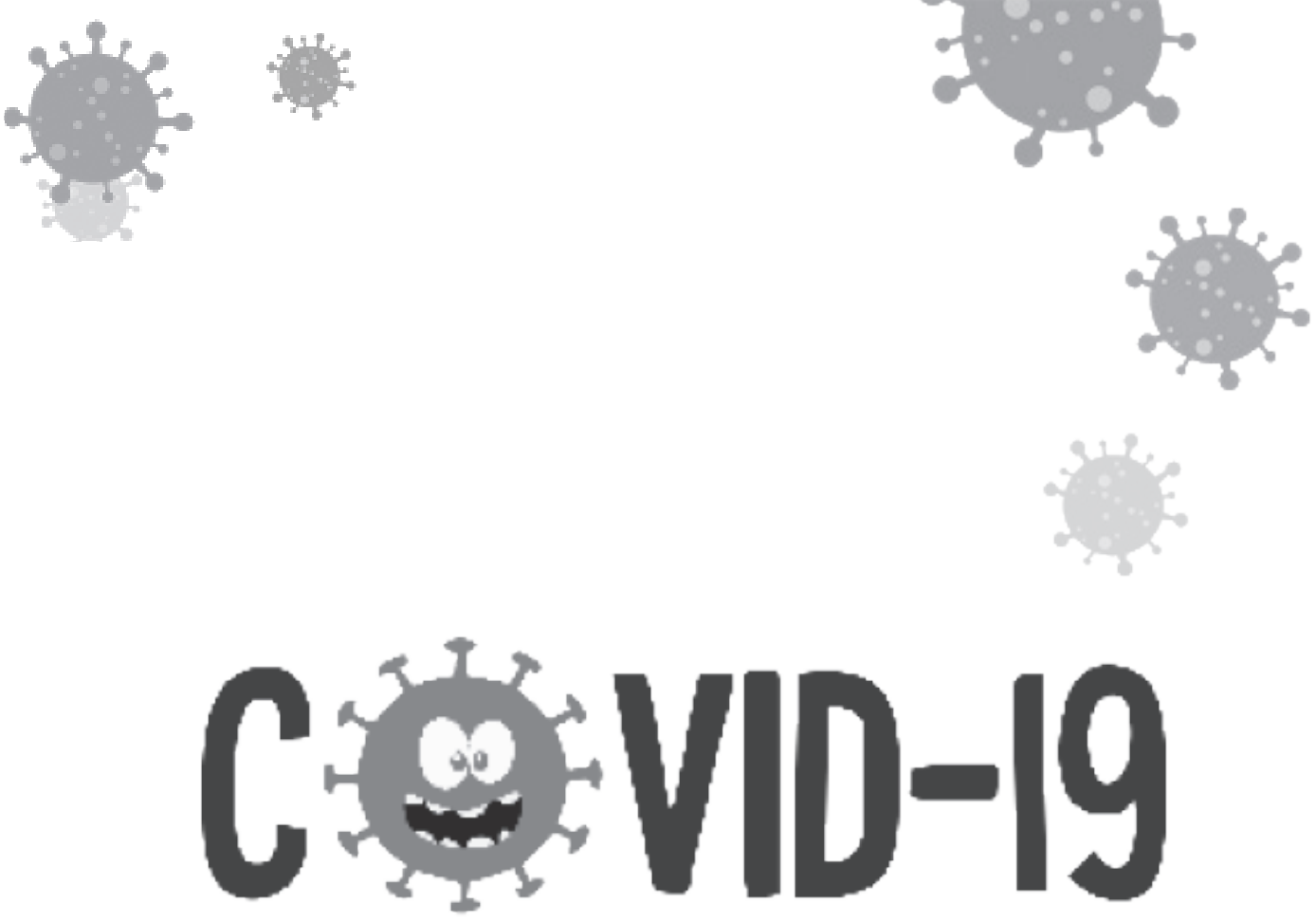

\section{THE NIGHTMARE OR RAINBOW}
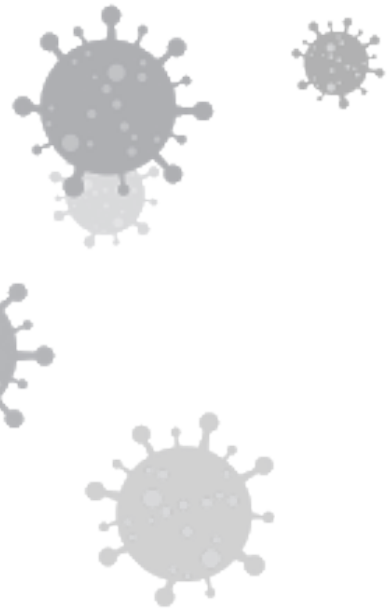


\section{Sanksi Pelanggaran Pasal 72:}

Undang-undang Nomor 19 Tahun 2002

\section{Tentang Hak Cipta}

1. Barangsiapa dengan sengaja melanggar dan tanpa hak melakukan perbuatan sebagaimana yang dimaksud dalam Pasal 2 Ayat (1) atau Pasal 49 Ayat (1) dan (2) dipidana dengan pidana penjara masing-masing paling singkat 1 (satu) bulan dan/atau denda paling sedikit Rp1.000.000 (setujuta rupiah), atau pidana penjara paling lama 7 (tujuh) tahun dan/atau denda paling banyak Rp5.000.000.000 (lima miliar rupiah).

2. Barangsiapa dengan sengaja menyiarkan, memamerkan, mengedarkan, atau menjual kepada umum suatu ciptaan atau barang hasil pelanggaran hak cipta atau hak terkait sebagai dimaksud pada Ayat (1) dipidana dengan pidana penjara paling lama 5 (lima) tahun dan/atau denda paling banyak Rp50.000.000 (lima puluh juta rupiah) 


\title{
COVID-19: \\ THE NIGHTMARE OR RAINBOW \\ (Edisi I-Update Maret 2020, Indo-English)
}

\author{
Penulis \\ Siti Rahayu \\ Sri Mardikani Nugraha \\ Christa Manik \\ Nariyah Handayani \\ Tince Jovina \\ Novi Budiati
}

Kolabrasi dengan

DR. Riant Nugroho (Ahli Kebijakan Publik)

\section{Thanks to}

Drg. Agus Suprapto, MKes (Reviuwer)

Dr. Nelly Puspandari, SPMK (Reviuwer)

\section{MataAksara}

Penerbit Mata Aksara

2020 
Hak pengarang dan penerbit dilindungi oleh undang-undang, dilarang mengutip dan memperbanyak tanpa seizin penerbit, sebagian atau seluruhnya dalam bentuk apa pun, baik cetak, photoprint, microfilm, dan sebagainya.

Perpustakaan Nasional Indonesia; Katalog dalam Terbitan (KDT)

Siti Rahayu dkk

COVID-19: THE NIGHTMARE OR RAINBOW oleh Siti Rahayu dkk --

Jakarta: Penerbit Mata Aksara, 2020

$272 \mathrm{hal} ; 21 \mathrm{~cm}$

ISBN: 978-602-5768-33-0

1. COVID-19: THE NIGHTMARE OR RAINBOW . I. Judul. II. Siti Rahayu dkk

Title

Author

Layout \& cover design

Editor
: COVID-19: THE NIGHTMARE OR RAINBOW

: Siti Rahayu, dkk

: Ratu Mucharani

: Tim Mata Aksara Publishing

Hak cipta dilindungi undang-undang

All rights reserved

Cetakan Pertama: Mei 2020

Buku ini diterbitkan oleh Penerbit Mata Aksara

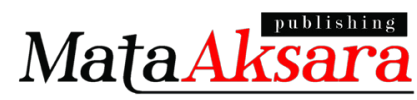

www.hanikamediaksara.com

email : penerbitmataaksara@gmail.com
Mata Aksara Publishing

Jln. Kelapa Hijau 23B

Jagakarsa, Jakarta Selatan

Telp: (021) 22712799 


\section{PENGANTAR PENERBIT}

Segala puji bagi Allah SWT yang telah berkenan memberikan anugerahNya sehingga buku bertajuk COVID-19: THE NIGHTMARE OR RAINBOW (Edisi I-Update Maret 2020, Indo-English) dapat terbit pada waktunya. Buku ini ditulis oleh para pakar analis kebijakan di bidang kesehatan khususnya di Badan Penelitian dan Pengembangan Kesehatan, Kementerian Kesehatan.

Buku ini merupakan implementasi dari fungsi sosialisasi ilmu pengetahuan khususnya terkait COVID-19 yang sekarang ini merupakan pandemi dan sedang kita lawan bersama. Mengingat hal tersebut, sudah seharusnya karya anak bangsa ini disampaikan ke masyarakat. Di sisi lain, buku ini juga bisa menjadi khasanah khususnya di bidang ilmu kesehatan, kebijakan publik, maupun subsistem pendukungnya.

Dengan segala keterbatasan dan kendala yang dihadapi, para pakar kita tetap bekerja keras dan semangat menekuni bidang kebijakan publik di ranah kesehatan, khususnya bahu-

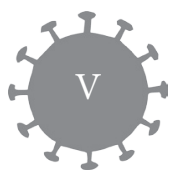


membahu dalam melawan pandemi COVID-19. Dengan buku ini kita bisa memahami asal muasal COVID-19, pencegahan dan penanganannya, sampai pada proses penyusunan kebijakan dan pengambilan keputusan, serta evaluasi terkait respon terhadap pandemi ini. Keterbukaan informasi ini tentunya sangat dibutuhkan oleh masyarakat.

Akhir kata, kami selaku penerbit bangga diberi kesempatan menjadi bagian penyebarluasan karya anak bangsa dalam bentuk penerbitan buku ini. Semoga buku ini dapat bermanfaat bagi kemajuan ilmu pengetahuan di bidang kesehatan maupun kebijakan publik, dan membawa Indonesia menjadi negara yang sehat dan sejahtera. Amin!

Penerbit

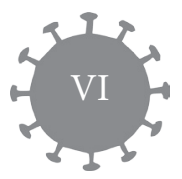




\section{DAFTAR ISI}

PENGANTAR PENERBIT

. $\mathbf{v}$

DAFTAR ISI vii

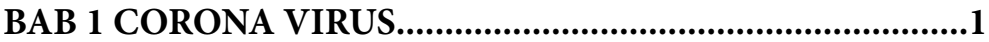

BAB 2 DAMPAK COVID-19..................................................37

BAB 3 KEBIJAKAN KESEHATAN COVID-19........................66

BAB 4 ANALISIS KEBIJAKAN COVID-19...........................92

BAB 5 REKOMENDASI PAKAR.......................................117

BAB 6 KESIMPULAN DAN SARAN................................135

\section{ENGLISH VERSION}

CHAPTER ONE

CORONA VIRUS (COVID-19).

CHAPTER TWO:

THE IMPACT OF (COVID-19) ..................................................165

CHAPTER THREE:

COVID-19HEALTHPOLICY

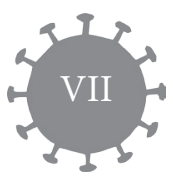




\section{CHAPTER FOUR:}

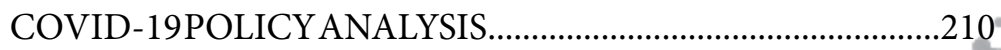

CHAPTER FIVE:

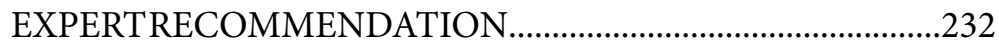

CHAPTER SIX:

CONCLUSIONANDRECOMMENDATION.............................246

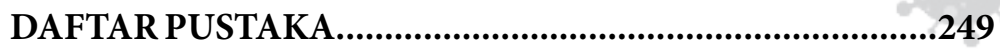

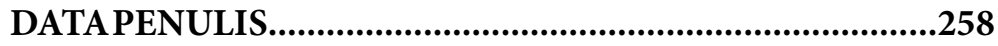




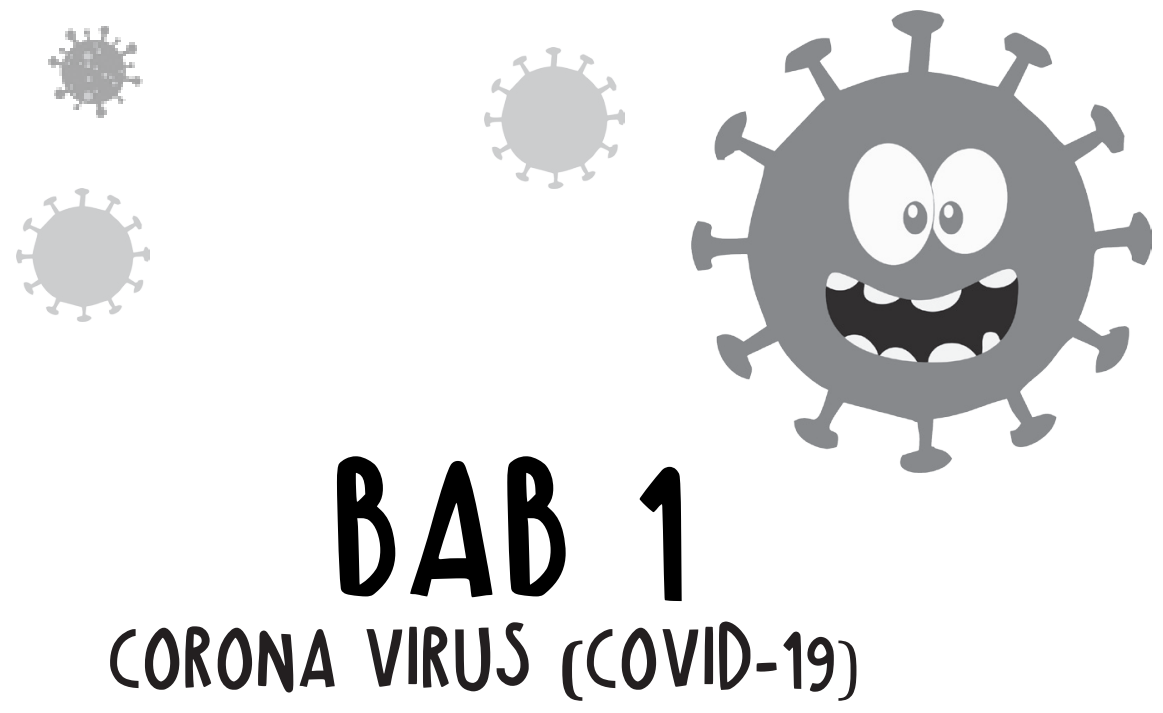

Sri Mardikani Nugraha ${ }^{1}$

\section{Pengertian Covid-19}

COVID-19 merupakan singkatan dari Coronavirus disease 2019 adalah penyakit jenis baru yang disebabkan oleh virus Severe Acute Respiratory Syndrome Coronavirus-2 (SARS-Cov-2) yang sebelumnya disebut Novel Coronavirus (2019-nCov). Virus baru ini sangat menular dan cepat menyebar secara global. Infeksi coronavirus ditandai

1. Analis Kebijakan Puslitbang Sumberdaya dan Pelayanan Kesehatan

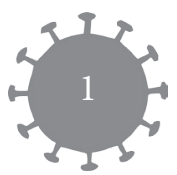


dengan demam dan gejala pernapasan seperti batuk, sesak napas, dan kesulitan bernapas. Pada kondisi parah dapat menyebabkan pneumonia, sindrom pernapasan akut, gagal ginjal, bahkan kematian.

Kasus penyakit ini bermula dari penemuan kasus pneumonia dengan etiologi tidak jelas di Wuhan, Provinsi Hubei, Cina yang diinformasikan WHO pada 31 Desember 2019. Kasus penyakit tersebut terus berkembang dan dilaporkan menyebabkan kematian serta menyebar ke luar Cina. Sesuai dengan International Health Regulation 2005, pada tanggal 30 Januari 2020 WHO menyatakan wabah ini sebagai Public Health Emergency of International Concern (PHEIC) atau kita sebut sebagai Kedaruratan Kesehatan Masyarakat yang Meresahkan Dunia/KKMMD karena telah menyebar ke 18 negara dengan 4 negara yang melaporkan transmisi ke manusia. Pada perkembangan selanjutnya Covid-19 menyebar ke 114 negara sehingga pada tanggal 11 Maret 2020 WHO menetapkan sebagai pandemik.

SARS-Cov-2 ditetapkan oleh International Committee on Taxonomy of Viruses (ICTV) dan diumumkan sebagai nama virus baru pada tanggal 11 Februari 2020. Karena berdasarkan hasil analisis filogenik, coronavirus yang menyebabkan Covid-19 adalah betacoronavirus, subgenus 
yang sama dengan SARS tetapi dalam clade yang berbeda. Struktur wilayah gen pengikat reseptor sangat mirip dengan coronavirus SARs. Virus ini juga terbukti menggunakan reseptor yang sama yaitu Angiotensin Converting Enzim- 2 (ACE2) untuk entri sel. Dalam analisis filogenetik dari 103 strain SARS-Cov-2 dari Tiongkok ada 2 jenis SARS-Cov-2 yaitu tipe L (mendominasi selama hari-hari awal epidemi di Tiongkok tetapi menyumbang proporsi strain yang lebih rendah di luar wuhan) dan tipe S. (Kenneth McIntosh, 2020). ${ }^{2}$

\section{Gambaran Covid-19}

Coronavirus telah menjadi patogen utama wabah penyakit pernafasan dan merupakan keluarga besar virus RNA yang dapat diisolasi pada spesies hewan yang berbeda. Virus ini dapat melintasi barrier spesies dan dapat menyebabkan penyakit pada manusia mulai dari flu biasa hingga yang lebih parah seperti MERS dan SARS, begitu juga dengan Covid-19.

Wabah Covid-19 dimulai di Wuhan pada bulan Desember 2019 dan menyebar ke seluruh benua kecuali

2 Kenneth McIntosh, Coronavirus disease 2019 (COVID-19), https://www.uptodate.com/contents/coronavirus-disease-2019-covid-19. Diunduh 20 Maret 2020 jam 9.00 am

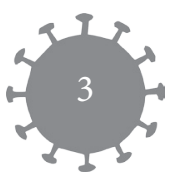


Antartika. Wabah penyakit ini juga ditetapkan sebagai darurat kesehatan masyarakat yang menjadi perhatian internasional dengan kode ICD-10 yaitu U07.1.

Selanjutnya Organisasi kesehatan dunia (WHO) pada bulan Februari 2020 menetapkan penyakit coronavirus 2019/Covid-19, yang disebabkan coronavirus baru (SARSCov-2) dan menjadi penyebab kasus pneumonia di Wuhan, Provinsi Hubei Tiongkok yang dengan cepat menyebar menjadi epidemi diikuti peningkatan jumlah kasus di negara-negara lain di seluruh dunia hingga ditetapkan menjadi Pandemi pada 11 Maret 2020.

SARS-Cov-2 dapat mengenai pada semua individu dari segala usia meskipun yang paling sering terkena orang dewasa usia pertengan dan lebih tua. Berdasarkan laporan dari Pusat Pengendalian dan Pencegahan Penyakit Tiongkok yang mencakup sekitar 44.500 pasien Covid-19 yang terkonfirmasi didapatkan $87 \%$ pasien berusia 30 79 tahun. Hasil penelitian Guan et all, usia median pasien adalah 47 tahun, $41,9 \%$ dengan jenis kelamin perempuan.

Tingkat fatalitas kasus 8\% pada usia 70-79 tahun dan 15\% pada usia 80 tahun atau lebih. Sedangkan di Amerika Serikat, dari 2449 pasien yang didiagnosa Covid-19 terdapat a $67 \%$ berusia $>45$ tahun. Kematian tertinggi pada individu 
yang lebih tua ( $>65$ tahun) yaitu $80 \%$. Kasus Covid-19 pada anak bisa terjadi, biasanya ringan meskipun kasus parah telah dilaporkan. Infeksi pada usia $<20$ tahun di Tiongkok dilaporkan hanya 2\% sedangkan di Korea Selatan 6,3\%.

\section{Etiologi}

Corona virus adalah virus RNA untai positif dengan penampilan seperti mahkota di bawah mikroskop elektron karena adanya lonjakan glikoprotein pada amplop. Seperti telah diketahui di atas, virus penyebab Covid-19 adalah SARS-Cov2 yang termasuk dalam kategori betacoronavirus.

Virus ini memiliki bentuk bulat atau ellips dan sering pleomorfik dengan diameter sekitar 60-140 nanometer dan sensitif terhadap sinar ultraviolet dan panas serta dapat dinonaktifkan oleh pelarut lipid seperti eter (70\%), etanol, desinfektan yang mengandung chlorin, asam peroksiasetat dan chloroform (kecuali chlorheksidin). Genom RNA untai tunggalnya mengandung 29891 nukleotida yang mengkode 9860 asam amino. Hasil analisis genom, menunjukkan SARS-cov-2 mungkin berevolusi dari strain yang ditemukan pada kelelawar ${ }^{3}$

3. Marco Cascella; Michael Rajnik; Arturo Cuomo; Scott C.

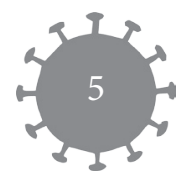



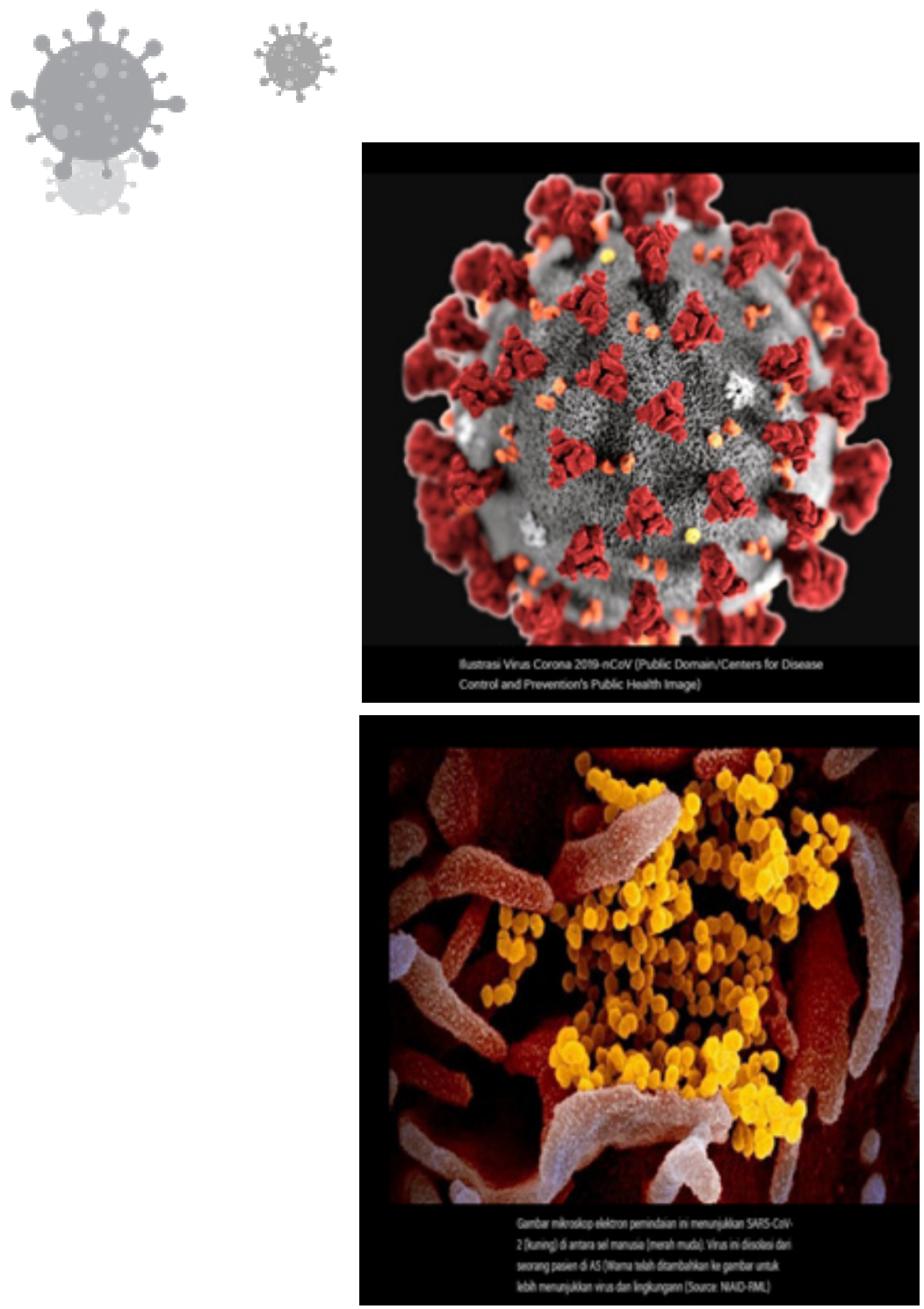

Elektron SARS-Cov-2 ${ }^{5}$

5. Sumber: https://www.liputan6.com/health/read/4180450/ mirip-dengan-mers-dan-sars-ini-gambar-virus-corona-baru-yangdirilis-peneliti-as

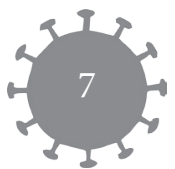



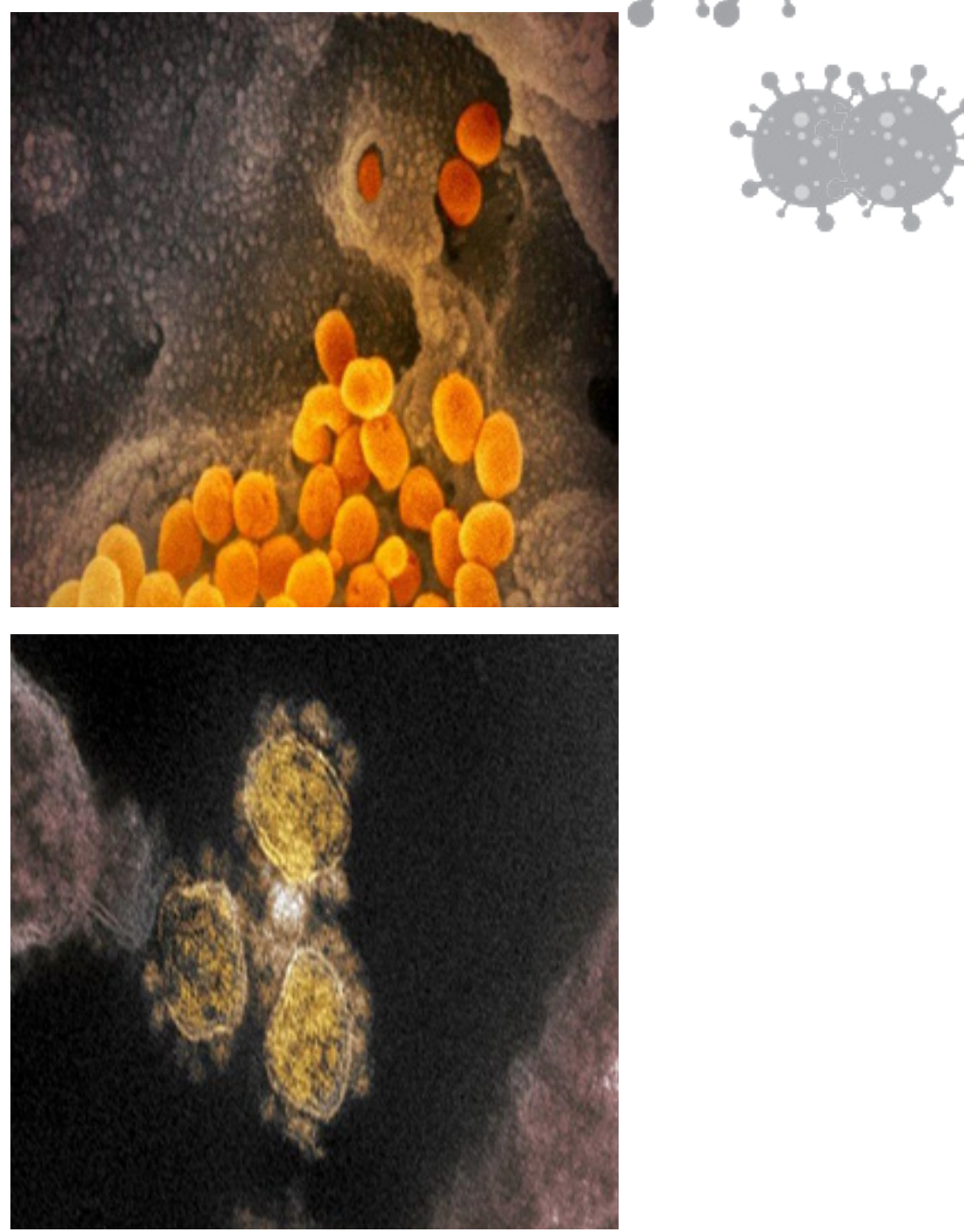

Gambar 1.3 Virus Corona yang di Perbesar ${ }^{6}$

6. Sumber: https://m.tribunnews.com/corona/2020/03/16/ berduri-ini-gambar-virus-corona-diperbesar-bentuk-corona-seperti-

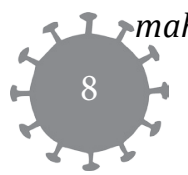


Berdasarkan hasil studi Kampf et all, dengan menganalisis 22 studi mengungkapkan bahwa coronavirus manusia seperti SARS-Cov, MERS-Cov atau H-Cov dapat bertahan pada permukaan benda mati seperti logam, kaca atau plastik selama 9 hari tetapi dapat dinonaktifkan secara efisien dengan prosedur desinfeksi permukaan dengan etanol $62-71 \%$, hydrogen peroksida $0,5 \%$ atau natrium hipoklorit $0,1 \%$ dalam 1 menit. Diharapkan hal tersebut memberikan efek yang sama dalam melawan SARS-Cov-2.

Lama virus corona bertahan di permukaan benda berbeda-beda. Lembaga Eikjman melalui facebook menyatakan bahwa virus corona dapat bertahan di benda masing-masing sebagai berikut: aluminium (2-8 jam), besi (48 jam), kaca (4 hari), plastik (5 hari), sarung tangan medis (8 jam), kertas (4-5 hari), dan kayu 4 hari.

\section{Transmisi/Penularan}

Penularan dari hewan ke manusia merupakan mekanisme utama pertama kali kasus Covid-19 di Wuhan karena terkait paparan langsung ke pasar grosir makanan laut Huanan. Kasus-kasus selanjutnya penularannya dari manusia ke manusia dan orang yang bergejala merupakan 
sumber penyebaran Covid-19 yang paling sering.

Penularan dari orang ke orang melalui kontak langsung dan percikan (droplet). Menurut sumber dari CDC penularan orang ke orang meliputi kontak erat satu sama lain dalam jarak sekitar 6 kaki dan melalui droplet. Pada penularan melalui droplet, virus dilepaskan dalam sekresi pernapasan ketika seseorang infeksi batuk, bersin atau berbicara. Hal tersebut dapat menginfeksi orang lain bila melakukan kontak langsung dengan selaput lendir. Droplet biasanya tidak bergerak lebih dari 6 kaki atau sekitar dua meter dan tidak berlama-lama di udara. Selain itu, seseorang mungkin bisa mendapatkan Covid-19 dengan menyentuh permukaan atau benda yang memiliki virus di atasnya kemudian menyentuh mulut, hidung atau mata mereka sendiri, tetapi ini bukan cara penularan yang utama. ${ }^{2}$ Transmisi aerosol juga dimungkinkan dalam kasus paparan yang berkepanjangan terhadap peningkatan konsentrasi aerosol di ruang tertutup. ${ }^{3}$

Penularan dari orang yang belum bergejala jarang terjadi, namun tidak dapat dikesampingkan. Pada buku Panduan Menghadapi Virus Corona 2019 Model RRC di Cina yang sudah diperbaharui, sumber infeksi utama adalah a pasien konfirmasi positiv Covid-19 dan pembawa (carier) 
Covid-19 yang tidak menunjukkan gejala klinis juga dapat menjadi sumber infeksi.

Informasi terakhir, WHO mengatakan penyakit pernapasan menyebar melalui kontak manusia ke manusia, butiran-butiran yang dibawa melalui bersin dan batuk serta kuman yang tertinggal pada benda mati. Virus corona dapat melayang di udara dan tetap menggantung di udara tergantung pada faktor panas dan kelembaban. Pejabat kesehatan merekomendasikan staf medisnya menggunakan masker N95 karena dapat menyaring semua partikel cair maupun udara/airborne sekitar $95 \% .^{7}$

\section{Masa Inkubasi}

Masa inkubasi merupakan periode saat pasien terpapar virus pertama kali sampai timbul gejala klinis. Masa inkubasi Covid-19 diperkirakan dalam 14 hari setelah paparan, namun sebagian besar kasus terjadi sekitar 4-5 hari setelah paparan. Hasil penelitian terhadap 1099 pasien positif Covid-19 yang dilakukan Guan et all, masa inkubasi

7. CNBC, 2020, WHO considers 'airborne precautions' for medical staff after study shows coronavirus can survive in air, $h t t p s: / /$ www.cnbc.com/2020/03/16/who-considers-airborne-precautionsfor-medical-staff-after-study-shows-coronavirus-can-survive-in-air. html. Diunduh 22 Maret 2020

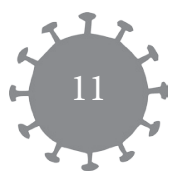


rata-rata adalah 4 hari dengan rentang interkuartil 2-7 hari. ${ }^{8}$

\section{Manifestasi Klinik dan Keparahan Penyakit}

Manifestasi klinik paling serius dari Covid-19 adalah pneumonia yang ditandai terutama dengan demam, batuk, sesak napas dan infiltrate di kedua paru pada pemeriksaan chest imaging. Tidak ada gambaran klinis spesifik yang dapat membedakan penyakit ini dengan infeksi pernapasan virus lainnya.

Hasil penelitian dari 138 pasien dengan pneumonia Covid-19 di Wuhan. Gejala klinis yang umum pada awal penyakit adalah demam (99\%), kelelahan dalam (70\%), batuk kering (59\%), anoreksia (40\%), myalgia (35\%), dispnea (31\%), produksi dahak (27\%). Dalam penelitian lain, demam dilaporkan pada hampir semua pasien tetapi sekitar 20\% memiliki demam dengan tingkat sangat rendah (<38 C). Gejala lain adalah sakit kepala, sakit tenggorokan dan rhinorea. Gejala gastrointestinal seperti mual dan diare juga dilaporkan pada beberapa pasien tetapi relative jarang gterjadi. Komplikasi utama pada pasien yang parah adalah acute respiratory distress syndrome (ARDS). Usia lebih 65 
tahun, diabetes mellitus dan hipertensi masing-masing dikaitkan dengan ARDS. Komplikasi lain aritmia, acut cardiac injury dan syok masing-masing dilaporkan $17,7 \%$ dan 9\%. Waktu pemulihan pasien Covid-19 menurut WHO sekitar 2 minggu untuk infeksi ringan dan 3-6 minggu untuk penyakit parah. Hasil temuan Guan et all, gejala Covid-19 yang paling umum adalah demam (43,8\% saat masuk dan $88,7 \%$ selama rawat inap), dan batuk $(67,8 \%)$. Gejala diare jarang terjadi, hanya 3,8\% kasus.

Spektrum klinis Covid-19 bervariasi mulai dari tanpa gejala/asimptomatik sampai kondisi klinis berat yang ditandai kegagalan pernapasan yang membutuhkan ventilasi mekanis dan perawatan di ICU hingga manifestasi multi organ dan sistemik, sepsis, syok septic dan sindrom disfungsi multiorgan. Penulis laporan Pusat pengendalian dan Pencegahan Penyakit Tiongkok, membagi manifestasi klinis penyakit Covid-19 berdasarkan tingkat keparahan sebagai berikut:

a. penyakit: ringan (non pneumonia atau pneumonia ringan) terjadi pada $81 \%$ kasus.

b. penyakit berat (dispnea, frekuensi pernapasan $>30 \mathrm{x} /$ menit, saturasi oksigen/SpO2 < 93\%, rasio $\mathrm{PaO} 2 / \mathrm{FiO} 2<300$ dan atau infiltrat paru $>$ 
50\% dalam 24-48 jam), terjadi pada 14\% kasus.

c. Penyakit kritis (gagal napas, syok septik atau disfungsi multiorgan) yang terjadi pada 5\% kasus. Tingkat fatalitas kasus secara keseluruhan adalah 2,3\%. Pada kasus-kasus non kritis tidak dilaporkan ada kematian. Menurut WHO, tingkat fatalitas kasus berkisar 5,8\% di Wuhan hingga 0,7\% di seluruh Tiongkok. Sebagian besar kasus fatal terjadi pada pasien usia lanjut atau komorbiditas medis yang mendasari di antaranya penyakit kardiovaskuler, diabetes mellitus, penyakit paru-paru kronis, hipertensi, dan kanker.

\section{Temuan Laboratorium}

Hasil laboratorium pasien Covid-19 paling umum dilaporkan adalah limfopenia. Kadar dehydrogenase laktat, ferritin dan kadar aminotransferase meningkat. Tingkat D-dimer yang tinggi dan limfopenia yang parah telah dikaitkan dengan kematian. Hasil penelitian Guan et all, didapatkan 83,2\% pasien Covid-19 saat masuk terdapat limfositopenia. CDC di USA merekomendasikan pengumpulan spesimen usap nasopharing untuk menguji SARS-Cov-2. Dahak hanya boleh dikumpulkan dari pasien

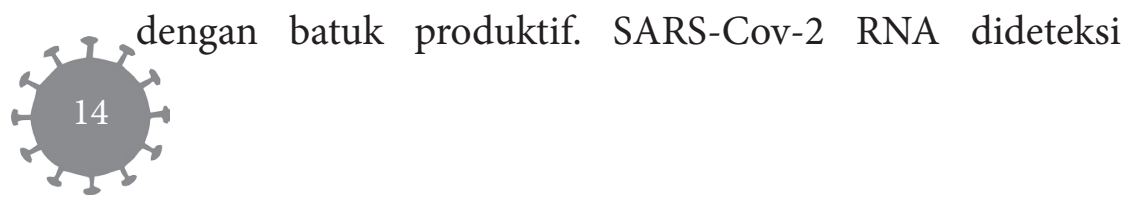


melalui reverse-transcription polymerase chain reaction (RT-PCR).

\section{Manajemen kasus}

Pendekatan manajemen awal harus fokus pada pengenalan dini kasus-kasus yang dicurigai, isolasi langsung, dan pelembagaan langkah-langkah pengendalian infeksi. Kemungkinan cCovid-19 harus dipertimbangkan pada pasien dengan demam dan atau gangguan saluaran pernapasan (batuk atau sesak) yang mengalami salah satu hal di bawah dalam 14 hari sebelumnya.

- Kontak dengan kasus covid-19 yang dikonfirmasi atau diduga termasuk mealui pekerjaan perawatan kesehatan. Kontak dekat termasuk berada dalam jarak kira-kira eam kaki (sekitar 2 meter) dari pasien untuk jangka waktu yang lama ketika tidak menggunakan peralatan pelindung pribadi atau kontak langsung dengan sekresi infeksius tanpa APD.

- Tinggal atau melakukan perjalanan ke daerahdaerah di mana penularan masyarakat dilaporkan meluas misal Cina, Korea Selatan Italia, Iran, Jepang.

- Potensi paparan melalui kehadiran di acara-acara 
atau menghabiskan waktu di mana kasus Covid-19 dilaporkan.

Kemungkinan Covid-19 juga harus dipertimbangkan pada pasien dengan penyakit saluran pernapasan bagian bawah yang parah ketika etiologic alternatif tidak dapat diidentifikasi atau belum ada paparan yang jelas. Ketika dicurigai Covid-19, langkah-langkah PPI harus dilaksanakan.

Pusat Pengendalian Dan Pencegahan Penyakit Amerika Serikat (CDC) mencatat bahwa keputusan untuk menguji SARS-Cov-2 harus didasarkan pada penilaian klinis dan mengingatkan dokter bahwa sebagian besar pasien Covid-19 yang dikonfirmasi mengalami demam dan atau gejala penyakit pernafasan akut misalnya batuk, sesak. CDC menyarankan memprioritaskan pasien rawat inap untuk menginformasikan keputusan pengendalia infeksi, individu bergejala yang memiliki risiko lebih tinggi terhadap hasil yang buruk misalnya usia $>65$ tahun, kondisi medis kronis, kondisi immunocompromise dan mereka dengan risiko pajanan tinggi (perjalanan terakhir ke lokasi tertentu, kontak dengan pasien Covid-19 atau menjadi pekerja kesehatan. 


\section{Definisi Kasus}

Definisi kasus menurut WHO dapat dilihat pada panduan teknisnya secara online. Di Indonesia menggunakan panduan yang dikeluarkan Kementerian Kesehatan RI yaitu Pedoman Pencegahan dan Pengendalian Coronavirus Disease (COVID-19) revisi ke-3, yang dikeluarkan pada tanggal 16 Maret 2020. Definisi kasus untuk keperluan surveillance berdasarkan WHO juga baru direvisi pada tanggal 20 Maret 2020 sebagai berikut:

\section{Kasus suspek adalah}

a. Seorang pasien dengan penyakit pernapasan akut (demam dan setidaknya satu tanda/gejala penyakit pernapasan misalnya batuk, sesak napas) DAN riwayat perjalanan ke atau tempat tinggal di lokasi yang melaporkan penularan komunitas penyakit Covid-19 selama 14 hari sebelum timbulnya gejala; ATAU

b. Seorang pasien dengan penyakit pernapasan akut DAN telah melakukan kontak dengan Covid-19 kasus yang konfirmasi atau kemungkinan dalam 14 hari terakhir sebelum timbulnya gejala; ATAU

c. Seorang pasien dengan penyakit pernapasan akut 
yang parah (demam dan setidaknya satu tanda/gejala penyakit pernapasan misalnya batuk, sesak napas DAN memerlukan rawat inap) DAN tanpa adanya diagnosis alternative yang sepenuhnya menjelaskan manifestasi klinis.

\section{Kasus probable:}

a. Kasus suspek yang memiliki hasil tes Covid-19 tidak dapat disimpulkan; ATAU

b. Kasus suspek yang tesnya tidak dapat dilakukan karena alasan apapun.

\section{Kasus konfirmasi:}

Seseorang dengan konfirmasi laboratorium infeksi covid-19, terlepas dari tanda dan gejala klinis. Sedangkan yang dimaksud dengan kontak adalah seseorang yang mengalami salah satu dari paparan berikut selama 2 hari sebelum dan 14 hari setelah onset dari gejala kasus probable atau kasus konfirmasi:

1. Kontak tatap muka dengan kasus probable atau kasus konfirmasi dalam jarak 1 meter dan lebih dari 15 menit

2. Kontak fisik langsung dengan kasus probable atau kasus konfirmasi 
3. Perawatan langsung untuk pasien kasus probable atau konfirmasi tanpa menggunakan alat pelindung diri yang tepat

4. Situasi lain seperti yang ditunjukkan oleh penilaian risiko lokal

Untuk kasus konfirmasi yang tanpa gejala, periode kontak diukur 2 hari sebelumnya hingga 14 hari setelah tanggal di mana sampel diambil yang mengarah ke konfirmasi. Di Indonesia, definisi kasus dalam surveillance tercantum dalam buku Pedoman Kesiapsiagaan Menghadapi Corona Disease 2019 (COVID-19) revisi ke-3 yang meliputi:

\section{Orang dalam Pemantauan (ODP) adalah}

Seseorang yang mengalami demam $(>380 \mathrm{C})$ atau riwayat demam atau gejala gangguan system pernapasan (pilek, batuk/sakit tenggorokan) DAN tidak ada penyebab lain berdasarkan gambaran klinis yang meyakinkan DAN pada 14 hari terakhir sebelum timbul gejala, memenuhi salah satu kriteria:

- Memiliki riwayat perjalanan atau tinggal di luar negeri yang melaporkan transmisi lokal

- Memiliki riwayat perjalanan atau tinggal di area transmisi lokal di Indonesia 
Pasien dalam Pengawasan (PDP) atau Suspek adalah:

1. Seseorang dengan ISPA yaitu demam ( $>38 \mathrm{C}$ ) atauriwayat demam disertai salah satu gejala pernapasan seperti batuk/sesak/sakit tenggorokan/pilek/ pneumonia ringan hingga berat, DAN Tidak ada penyebab lain berdasarkan gambaran klinis yang meyakinkan DAN pada 14 hari terakhir sebelum timbul gejala, memenuhi salah satu kriteria berikut:

- Memiliki riwayat perjalanan atau tinggal di luar negeri yang melaporkan transmisi lokal - Memiliki riwayat perjalanan atau tinggal di area transmisi lokal di Indonesia

2. Seseorang dengan demam ( $>38 \mathrm{C})$ atau riwayat demam atau ISPA DAN pada 14 hari terakhir sebelum timbul gejala memiliki riwayat kontak dengan kasus konfirmasi atau probable COVID-19

3. Seseorang dengan ISPA berat/pneumonia berat di area transmisi lokal di Indonesia yang membutuhkan perawatan di rumah sakit DAN tidak ada penyebab lainnya berdasarkan gambaran klinis yang meyakinkan.

Kasus Probabel adalah Pasien dalam pengawasan yang diperiksa COVID-19 tetapi inkonklusif, sedangkan 
Kasus konfirmasi adalah Seseorang terinfeksi COVID-19 dengan hasil pemeriksaan laboratorium posistif. Sedangkan kontak erat adalah seseorang yang melakukan kontak fisik atau berada dalam ruangan atau berkunjung (dalam radius 1 meter dengan kasusu pasiem dalam pengawasan, probable, atau konfirmasi) dalam 2 hari sebelum kasus timbul gejala dan hingga 14 hari setelah kasus timbul gejala. Kontak erat dikategorikan menjadi dua yaitu 1) Kontak erat risiko rendah dan bila kontak dengan kasus PDP. 2) Kontak erat risiko tinggi, bila kontak dengan kasus konfirmasi atau probabel.

\section{Pengobatan}

Tidak ada terapi antivirus khusus yang direkomendasikan untuk Covid-19 dan tidak ada vaksin sampai saat ini. Perawatan dilakukan simptomatik dan terapi oksigen untuk pasien dengan infeksi berat. Untuk kasus-kasus kegagalan pernapasan yang refrakter terhadap terapi oksigen mungkin diperlukan ventilasi mekanik dan dukungan hemodinamik sangat pentik untuk mengelola syok septik. Dari pengalaman negara yang sudah banyak pasien sembuh dan hasil penelitian bahwa invitro, Chloroquin dan hydroxychloroquin memiliki aktivitas 
antivirus di mana keduanya dapat mengurangi replikasi virus. Namun, hydroxykhloroquin menunjukkan aktivitas anti SARS-Cov-2 in vitro yang lebih baik. ${ }^{9}$ Karena masih belum ditemukannya terapi khusus yang tersedia untuk SARS-Cov-2, penanganan awal dan pencegahan penyebaran lebih lanjut akan sangat penting untuk menghentikan wabah yang sedang berlangsung dan untuk mengendalikan infeksi Novel Coronavirus. ${ }^{10}$

\section{Pecegahan}

Tindakan pencegahan merupakan strategi untuk membatasi penyebaran kasus. Strategi pencegahan difokuskan pada isolasi pasien dan pengendalian infeksi secara hati-hati termasuk langkah-langkah yang tepat untuk diadopsi selama diagnosis dan pemberian perawatan klinis kepada pasien yang terinfeksi. Organisasi

9. Xueting Yao, Fei Yei, Miao Zhang, Cheng Cui, et all, 2020, n Vitro Antiviral Activity and Projection of Optimized Dosing Design of Hydroxychloroquine for the Treatment of Severe Acute Respiratory Syndrome Coronavirus 2 (SARS-CoV-2), Diunduh dari https://academic.oup.com/cid/advance-article-abstract/ doi/10.1093/cid/ciaa237/5801998 oleh pengguna KERIS National Access pada 21 Maret 2020

10. Kampf a, D. Todt, S. Pfaender, E. Steinmann, 2020, Persistence of coronaviruses on inanimate surfaces and their inactivation with 
Kesehatan Internasional (WHO) dan organisasi lain telah mengeluarkan rekomendasi umum di antaranya hindari kontak dekat dengan subyek yang menderita infeksi pernapasan akut (Physical Distancing), cuci tangan sesering mungkin terutama setelah kontak dengan orang yang terinfeksi atau lingkungannya, hindari kontak tanpa perlindungan dengan peternakan atau hewan liar, orang dengan gejala infeksi saluran napas akut harus menjaga jarak, menutupi batuk atau bersin dengan tissue atau kain sekali pakai dan mencuci tangan, memperkuat langkahlangkah kebersihan yang ketat untuk pencegahan dan pengendalian infeksi khususnya departemen darurat medis, individu yang immunocompromise harus menghindari pertemuan publik.

Strategi yang paling penting dilakukan masyarakat adalah sering cuci tangan, menggunakan handsanitizer dan menghindari kontak langsung dengan orang lain. Serta petugas kesehatan yang merawat pasien terinfeksi harus menggunakan tindakan pencegahan dengan menggunakan APD seperti masker N95, pelindung mata, baju, dan sarung tangan untuk mencegah penularan.

Rekomendasi standar dari WHO dan Kementerian Kesehatan untuk mencegah penyebaran infeksi termasuk 
mencuci tangan secara teratur, menutupi mulut dan hidung ketika batuk dan bersin, memasak daging dan telur dengan saksama. Hindari kontak dekat dengan siapa pun yang menunjukkan gejala penyakit pernapasan seperti batuk dan bersin.

\section{Sebaran COVID-19}

Secara global, data dashboard WHO pada tanggal 3 Maret 2020 melaporkan 87.137 kasus positif Covid-19 yang terkonfirmasi di seluruh dunia sejak awal epidemi. Jumlah kematian ada 2.977 (3,4\%). Sekitar 92\% (79.968) kasus konfirmasi berasal dari Tiongkok dan hampir semua kematian juga tercatat di Cina yaitu 2.873 kasus. Di luar Cinabvgnjhy8u ada 7.169 kasus yang konfirmasi di 59 negara. Sepuluh besar negara terbanyak jumlah kasusnya di luar Cina di antaranya Republik Korea (3.736 kasus), Italia (1.128), pengangkutan internasional/Diamond Princess (705 kasus), Iran (593), Jepang (239), Singapura (102), Perancis (100), USA (62), Jerman (57), Kuwait (45), Spanyol (45) dan Thailand (42).

Informasi sebaran Covid-19 tersebar secara online baik tingkat global, negara, maupun lokal. Informasi 


\section{\%?}

disajikan setiap hari dan selalu up to date. Berdasarkan informasi data dari WHO Secara global sampai tanggal 19 Maret tercatat lebih dari 200.000 kasus konfirmasi Covid-19 telah dilaporkan, 8.778 kasus kematian dan 167 negara terjangkit. Sumber data Mutahir epdemiologi pandemik global dapat dilihat pada: The WHO Novel Coronavirus (COVID-19) Situation Board dan The John Hopkins Center for Systems Science and Enginering site for Coronavirus Global Cases COVID-19.

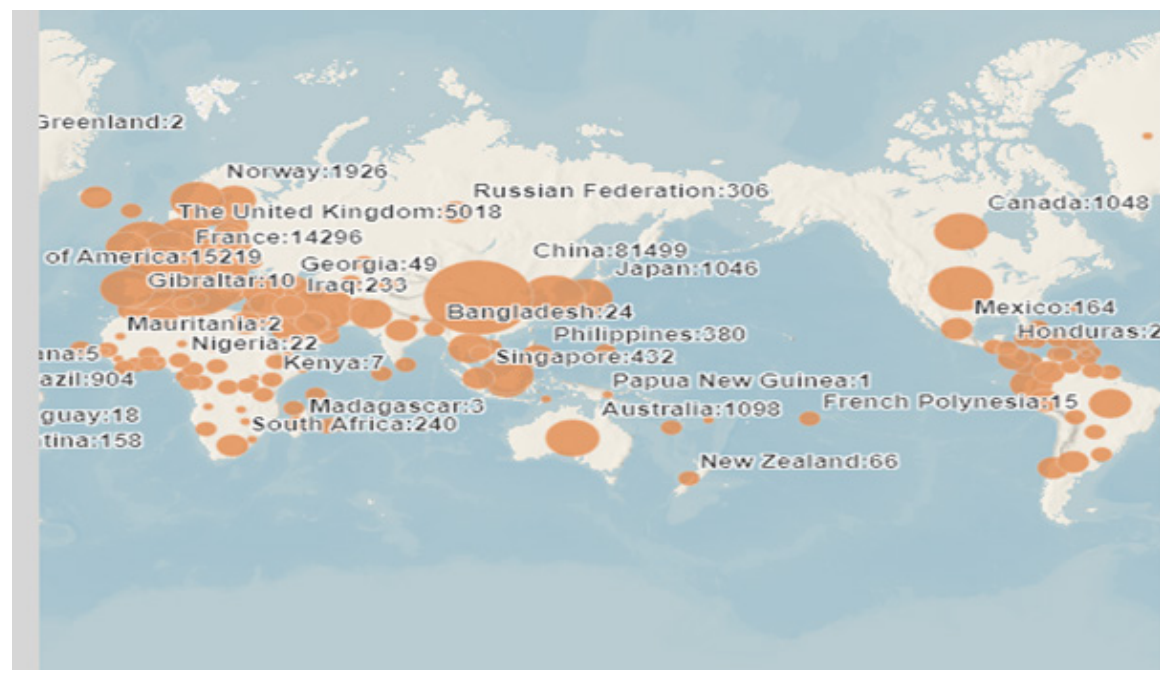

Gambar 1.4 Sebaran COVID-19 per 3 Maret 2020 ${ }^{11}$

11. Sumber: https://www.who.int/emergencies/diseases/novelcoronavirus-2019 
Di Indonesia persebaran kasus Covid-19 diawali dengan ditemukannya dua kasus positif warga Depok yang diumumkan pemerintah pada tanggal 8 Maret 2020. Dengan ditemukannya kasus konfirmasi tersebut pemerintah Indonesia menyatakan status waspada. Kasus positif berkembang dan bertambah setiap hari hingga 16 Maret terdapat 117 kasus konfirmasi positif Covid-19. Wilayah terjangkit/melaporkan kasus positif covid-19 adalah DKI Jakarta, Jawa Barat (kabupaten Bekasi, Depok, Cirebon, Bandung, Purwakarta), Jawa Tengah (Solo), Kalimantan Barat (Pontianak), Sulawesi Utara (Manado), Bali, Banten (Kab. Tangerang, Kota Tangerang, Kota Tangerang Selatan), dan DI Yogyakarta.

Sebaran kasus per 20 Maret 2020 pukul 08.00 WIB dengan sumber data dari Kementerian Kesehatan didapatkan bahwa sejak 30 Desember 2019 sampai 20 Maret terdapat 309 kasus konfirmasi posistif Covid-19 (15 sembuh dan 25 meninggal). Secara akumulasi terdapat 1.898 orang yang diperiksa dari 28 provinsi dengan hasil pemeriksaan: 1.570 orang negative (188 orang ABK kru kapal World Dream dan 68 orang ABK Diamond Princess), 
dan 21 sampel masih dalam pemeriksaan ${ }^{12}$.

Di Indonesia, wilayah yang melaporkan kasus konfirmasi yang penularannya secara lokal di wilayahnya adalah DKI Jakarta, Banten (Kabupaten Tangerang dan Kota Tangerang), Jawa Barat (Kabupaten Bekasi, Kota Bekasi dan Depok) dan Jawa Tengah (Solo).

\begin{tabular}{|c|c|c|c|c|c|c|c|c|c|c|}
\hline \multirow{2}{*}{ no } & \multirow{2}{*}{ PROVINSI } & \multicolumn{3}{|c|}{$\begin{array}{l}\text { JUMLAH KASUS } \\
\text { TANGGAL } 19 \text { MARET } 2020\end{array}$} & \multicolumn{3}{|c|}{$\begin{array}{l}\text { JUMLAH KASUS DENGAN } \\
\text { FOLLOWUP SPESIMEN } 2 \text { X NEGATIF }\end{array}$} & \multicolumn{3}{|c|}{ JUMLAH KASUS MENINGGAL } \\
\hline & & $\begin{array}{l}\text { SNO } 18 \\
\text { MARET } 2020\end{array}$ & $\begin{array}{l}19 \text { Maret } \\
2020\end{array}$ & $\begin{array}{l}\text { Kasus } \\
\text { KumuLATIF }\end{array}$ & $\begin{array}{c}\text { SID } 18 \\
\text { MARET } \\
2020\end{array}$ & $\begin{array}{c}19 \\
\text { MARET } \\
2020\end{array}$ & KUMULATIF & $\begin{array}{c}\text { S/D } 18 \\
\text { MARET } \\
2020\end{array}$ & $\begin{array}{c}19 \\
\text { MARET } \\
2020\end{array}$ & KUMULATIF \\
\hline 1 & mens & 1 & 0 & 1 & 0 & 0 & 0 & 1 & 0 & 1 \\
\hline 2 & Denten & 17 & 10 & 27 & 1 & 0 & 1 & 1 & 0 & 1 \\
\hline 3 & DI YOOYAACANTA & 3 & 2 & 5 & 0 & 0 & 0 & 0 & 0 & 0 \\
\hline 4 & DEo _akaveta & 158 & 52 & 210 & 9 & 4 & 13 & 12 & 5 & 17 \\
\hline 5 & JWWA BNGAT & 24 & 2 & 26 & 1 & 0 & 1 & 1 & 0 & 1 \\
\hline 6 & JaWA TENONG & 8 & 4 & 12 & 0 & 0 & 0 & 2 & 1 & 3 \\
\hline 3 & JwWa TaAuR & 8 & 1 & 9 & 0 & 0 & 0 & 1 & 0 & 1 \\
\hline 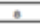 & GOLEUNGTAN BNEAT & 2 & 0 & 2 & 0 & 0 & 0 & 0 & 0 & o \\
\hline 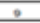 & 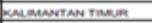 & 1 & 2 & 3 & 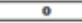 & 0 & 0 & 0 & 0 & \\
\hline 10 & 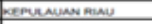 & 1 & 2 & 3 & 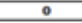 & 0 & 0 & 0 & 0 & 0 \\
\hline 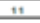 & SULAWESI UTARA & 1 & 0 & 1 & $\circ$ & 0 & 0 & 0 & 0 & 0 \\
\hline 12 & SUMATERA UTANA & 1 & 1 & 2 & 0 & 0 & 0 & 1 & 0 & 1 \\
\hline 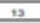 & SULAWESE TENOCNRA & 0 & 3 & 3 & 0 & 0 & 0 & 0 & 0 & 0 \\
\hline 34 & SULAWESI SFLATMN & 0 & 2 & 2 & 0 & 0 & 0 & 0 & 0 & 0 \\
\hline is & Laminum & 1 & 0 & 1 & 0 & 0 & 0 & 0 & 0 & 0 \\
\hline \multirow[t]{3}{*}{16} & Dow & 1 & 1 & 2 & 0 & 0 & 0 & 0 & 0 & 0 \\
\hline & TOTAL & 227 & 82 & 309 & 11 & 4 & 15 & 19 & 6 & 25 \\
\hline & GRAND TOTAL & & & & & & & & & 25 \\
\hline
\end{tabular}

Gambar 1.5 Sebaran Kasus COVID-19 di Indonesia ${ }^{13}$

12. Sumber https://covid19.kemkes.go.id/situasi-infeksi-emerging/ info-corona-virus/situasi-terkini-perkembangan-coronavirusdisease-covid-19-20-maret-2020/

13. Sumber https://infeksiemerging.kemkes.go.id/

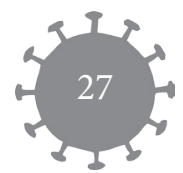



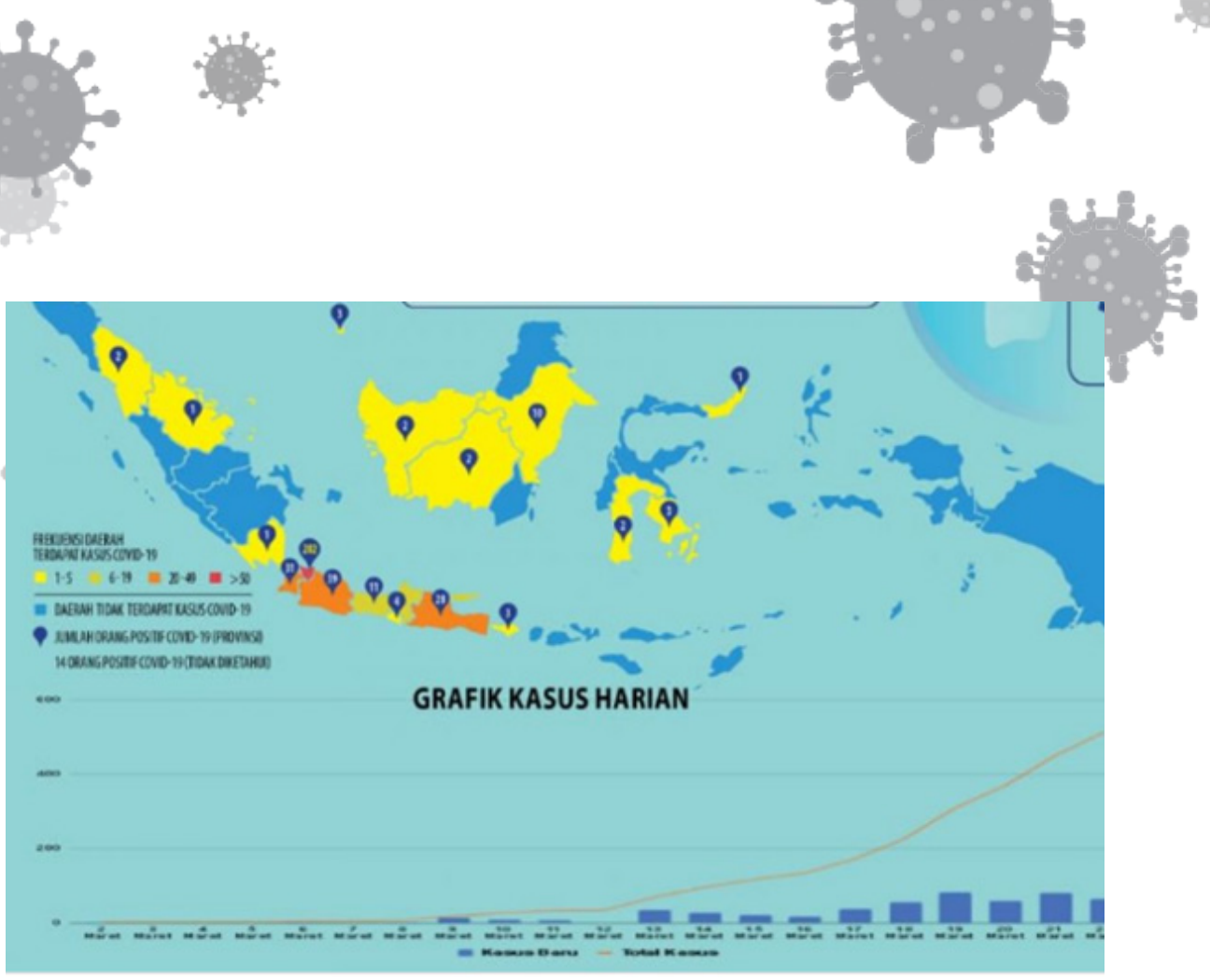

Gambar 1.6 Grafik Sebaran Harian COVID-19 di Indonesia

\section{Update Kasus Covid-19 per 20 Maret 2020}

a. Data Organisasi Kesehatan Dunia (WHO)

Update sementara perkembangan kasus Covid-19 secara global menggunakan sumber data WHO situation report didapatkan data yang masuk dan dilaporkan pada 20

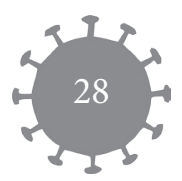


Maret $2020^{14}$ dan data tersebut dimungkinkan akan terus mengalami pertambahan disesuaikan dengan pertambahan hari kasus terjadi, sebagai berikut:

\begin{tabular}{|c|c|c|c|}
\hline No & Situasi & $\begin{array}{c}\text { Jumlah } \\
\text { Konfirmasi }\end{array}$ & $\begin{array}{c}\text { Jumlah } \\
\text { Kematian }\end{array}$ \\
\hline 1. & Global & $266.073(32.000)$ & $11.184(1.344)$ \\
\hline 2. & $\begin{array}{c}\text { Western Pasific } \\
\text { Region }\end{array}$ & $94.037(688)$ & $3.426(21)$ \\
\hline 3. & European Region & $128.541(23.950)$ & $6.000(1.101)$ \\
\hline 4. & $\begin{array}{c}\text { South-East Asia } \\
\text { Region }\end{array}$ & $979(61)$ & $38(7)$ \\
\hline 5. & $\begin{array}{c}\text { Eastern } \\
\text { Mediterranean } \\
\text { Region }\end{array}$ & $22.355(1.596)$ & $1.466(154)$ \\
\hline 6. & $\begin{array}{c}\text { Region of the } \\
\text { Americas }\end{array}$ & $18.877(5.606)$ & $235(57)$ \\
\hline 7. & African Region & $572(99)$ & $12(4)$ \\
\hline
\end{tabular}

Tabel 1.1 Jumlah Kasus Sementara COVID-19 Secara Global

Selanjutnya, data lainnya menyebutkan sepuluh besar negara yang mempunyai kasus konfirmasi COVID-19 per tanggal 20 Maret 2020 dan masih di presdiksi akan terus bertambah disesuaikan dengan pertambahan hari dan

14. Sumber: www.who.int

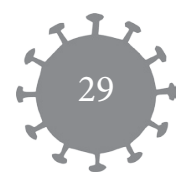


efektifitas kebijakan yang diambil oleh masing-masing negara.

Dari data yang ada dijelaskan bahwa Tiongkok masih berada di posisi pertama jumlah kasus COVID-19 sebanyak 81.416kasus, kemudian Italia sebanyak 47.021 kasus, Spanyol sebanyak 19.980 kasus, Iran sebanyak 19.644 kasus, Jerman sebanyak 18.323 kasus, Amreika Serikat sebanyak 15.219 kasus, Perancis sebanyak 12.475 kasus, dan Korea Selatan sebanyak 8.799 kasus. Jumlah kasus masih terus berubah setiap harinya dan dapat berubah sewaktu-waktu sesuai dengan kebijakan dan strategi yang diambil oleh masingmasing negara. Sedangkan untuk data perkembangan kasus COVID-19 di Indonesia terangkum dalam data satu pintu yang disajikan oleh Kementerian Kesehatan, yang terupdate setiap harinya melalui website, whatsapp, dan sosial media lainnya.

b. Data Kementerian Kesehatan

Perkembangan kasus berdasarkan informasi website Kementerian Kesehatan sebagai berikut: 
COVID-19 Update hingga 22 Maret 2020 Pukul 17.00 WIB

\begin{tabular}{|c|c|c|}
\hline Global & China & Terdampak \\
\hline 266.073 & 81.416 & 179 \\
\hline $\begin{array}{c}\text { Kasus Konlmasi } \\
11 \text { 194 }\end{array}$ & Kasus Koofmas & Negara Teranga \\
\hline $\begin{array}{l}11.184 \\
\text { Kosus Meingay }\end{array}$ & $\begin{array}{l}72.440 \\
\text { Kasus Sembeh }\end{array}$ & 98 \\
\hline $\begin{array}{c}4,2 \% \\
\text { Anga Kenatian }\end{array}$ & $\begin{array}{c}3.261 \\
\text { Kasus Meningeal }\end{array}$ & $\begin{array}{l}\text { Negara Transmisi } \\
\text { Loks }\end{array}$ \\
\hline
\end{tabular}

\section{RISIKO TINGGI GLOBAL}

Sumber: WHO
Situasi Kasus di Indonesia (Sumber : PHEOC Kemkes RI)

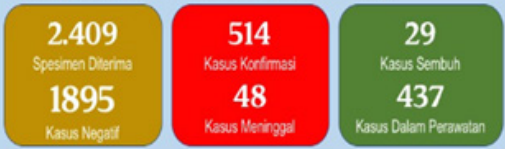

Wilayah Transmisi Lokal:

DK Jakarta, Banten (Kab. Tangerane, Kota Tangerang), Jawa Barat (Kab. Belasi, Kota Bekasi, Depok), Jawa Tengah (Solo), lawa Timur (Malang dan Surabaya)

\section{Negara Terjangkit Transmisi Lokal:}

Afriba Selatan, Albania, Ageria, Amerika Serikat, Arab Savol, Argertina, Armenia, Australia, Aastria, Bahamas, Bahrain, Bangladesh, Belga, Belanda, Belarusia, Bolivia.

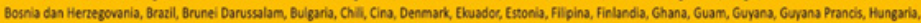

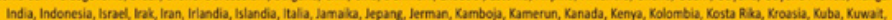
Lebanon, Lberia, Luksemburz, Makedonia Utara, Malsysia, Maldives, Maroba, Mesir, Norwegia, Oman, Palestina, Panama, Paraguay, Perancis, Peru, Polandia, Poctugal, Qatar, Republik Ceiko, Republik Dominikan, Republik Demokratik Kongo, Repubilik Korea, Republik Moldowa, Rumania, Rwanda, Sun Marino, Selandia, Baru, Senegal, Serbia,

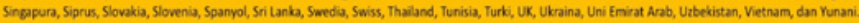

kemkes.goid/category/situasi-infeksi-emerging/info-corona-virus:

Gambar 1.7 Data Kemenkes Terkait COVID-19 per tanggal 22 Maret $2020^{15}$

Gambar 1.8 Data Kasus COVID-19 per Provinsi di Indonesia ${ }^{16}$ LAPCRAN MEOLA HARLAN CONID 19 TANGGAL 21 MARET 2015 PUXUL 13.00 WB

\begin{tabular}{|c|c|c|c|c|c|c|c|c|c|c|}
\hline \multirow{2}{*}{$\infty$} & \multirow{2}{*}{ Poovers: } & \multicolumn{3}{|c|}{$\begin{array}{l}\text { JuM aH Kasus } \\
\text { Tavical 21 Masert novo }\end{array}$} & \multicolumn{3}{|c|}{ 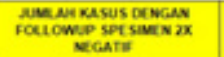 } & \multicolumn{3}{|c|}{ JMLAH Kasus Minivocal. } \\
\hline & & $\begin{array}{l}5020 \\
\text { net } \\
200\end{array}$ & $\sum_{\operatorname{mas}}^{21}$ & $\begin{array}{c}\text { Kusys } \\
\text { KINUIATE }\end{array}$ & $\begin{array}{c}50 x 0 \\
\text { maset } \\
\operatorname{les} 1\end{array}$ & $\underset{\substack{x \\
\text { maxt } \\
\text { nax }}}{x}$ & numears & $\begin{array}{l}\operatorname{sox} x \\
\operatorname{maset} \\
\operatorname{man}\end{array}$ & 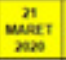 & susarat: \\
\hline$t$ & $s e$ & 3 & $\theta$ & 3 & $\theta$ & $\theta$ & 9 & 1 & $\theta$ & 1 \\
\hline 2 & avis: & 3 & 4 & 43 & $\mathbf{1}$ & 0 & 1 & 1 & 1 & 2 \\
\hline 3 & progrkents & 4 & 1 & 5 & 0 & $t$ & 1 & $\theta$ & 0 & 0 \\
\hline$\leftarrow$ & bosacurta & 203 & 44 & 267 & 14 & 3 & ty & 16 & 5 & 23 \\
\hline 5 & Lawa buev? & 41 & 14 & 55 & 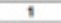 & $\theta$ & 1 & 7 & $\theta$ & 7 \\
\hline 4 & Lana Trokn & 12 & 2 & 14 & e & $\theta$ & 9 & 3 & 0 & 3 \\
\hline 7 & What The & is & 11 & 26 & 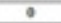 & 0 & 0 & 9 & $\theta$ & 1 \\
\hline 4 & Cosmortav eutent & 2 & 0 & 2 & $\theta$ & 0 & 0 & 0 & 0 & 9 \\
\hline$\bullet$ & wamertas rasa & 9 & 6 & 9 & 9 & 0 & 0 & $\theta$ & 0 & 6 \\
\hline th & 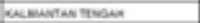 & 2 & $\theta$ & 2 & $\theta$ & $\theta$ & $\theta$ & $\theta$ & $\theta$ & $\theta$ \\
\hline 18 & enucas bese & 4 & 8 & 4 & $\theta$ & $\theta$ & 9 & 9 & $\theta$ & 9 \\
\hline 12 & Buanes vitan & 1 & 0 & 1 & $\theta$ & $\theta$ & 0 & 6 & 0 & 9 \\
\hline 19 & 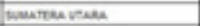 & 2 & 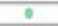 & 2 & 0 & 0 & 0 & 1 & $\theta$ & 1 \\
\hline 16 & suckints Trobest & 3 & $\theta$ & 3 & 9 & 0 & 0 & 6 & 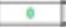 & 0 \\
\hline is & 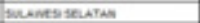 & $\theta$ & 2 & 2 & 9 & 8 & $\theta$ & 9 & $\theta$ & $\theta$ \\
\hline * & anosos & 1 & $\bullet$ & 1 & 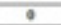 & $\theta$ & 9 & 9 & $\theta$ & 9 \\
\hline \multirow[t]{4}{*}{17} & tove & 1 & 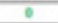 & 1 & 0 & 0 & 0 & 0 & 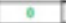 & 9 \\
\hline & 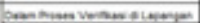 & $y$ & 3 & 10 & 0 & 0 & 0 & $\theta$ & 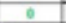 & 0 \\
\hline & DOTAL & 363 & 19 & 450 & 16 & 4 & 20 & $n$ & 6 & 38 \\
\hline & CeNW TOTM & & & & & & & & & 30 \\
\hline
\end{tabular}

\section{Data Badan Nasional Penanggulangan Bencana}

15. Sumber: https://infeksiemerging.kemkes.go.id/

16. Sumber: https://infeksiemerging.kemkes.go.id/

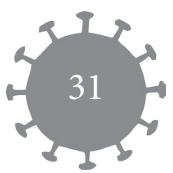




\section{(BNPB)}

Perkembangan kasus di Indonesia menggunakan data satu pintu dari BNPB yang ditunjuk sebagai gugus depan COVID-19 serta dari konferensi pers oleh Kementerian Kesehatan yaitu https://www.covid19.go.id. Situasi COVID-19 per tanggal 20 Maret 2020 sebagai berikut:

\begin{tabular}{|c|c|c|c|}
\hline \multicolumn{2}{|c|}{ Situasi Global } & \multicolumn{2}{c|}{ Situasi Indonesia } \\
\hline Kasus & Jumlah & Kasus & Jumlah \\
\hline Negara/Kawasan & $\begin{array}{c}159(8 \\
\text { baru) }\end{array}$ & Positif Covid-19 & 450 \\
\hline $\begin{array}{c}\text { Kasus terkonfir- } \\
\text { masi }\end{array}$ & 244.525 & $\begin{array}{c}\text { Sembuh (positif } \\
\text { Covid-19) }\end{array}$ & 20 \\
\hline Sembuh & 86.032 & $\begin{array}{c}\text { Meninggal (positif } \\
\text { Covid-19) }\end{array}$ & 38 \\
\hline Kematian & 10.031 & & \\
\hline
\end{tabular}

Gambar 1.9 Tabel Situasi COVID-19 sesuai Data BNPB ${ }^{17}$

Data di atas menunjukkan bahwa per tanggal 20 Maret 2020 kasus di Indonesia sebanyak 450 orang positif, sembuh sebanyak 20 orang dan meninggal sebanyak 38 orang. Kasus tersebut mengalami peningkatan yang sangat signifikan di mana pada tanggal 22 Maret 2020 menurut data bahwa jumlah kasus di Indonesia adalah kasus positif sebanyak 


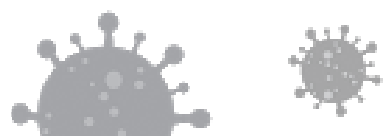

514 orang, sembuh 29 orang, dan meninggal sebanyak 48 orang. ${ }^{18}$

PeningkatanjumlahkasusCOVID-19dansebarannya per tanggal 26 Maret 2020 di Indonesia dapat dilihat pada gambar peta sebaran secara akumulatif di bawah ini:

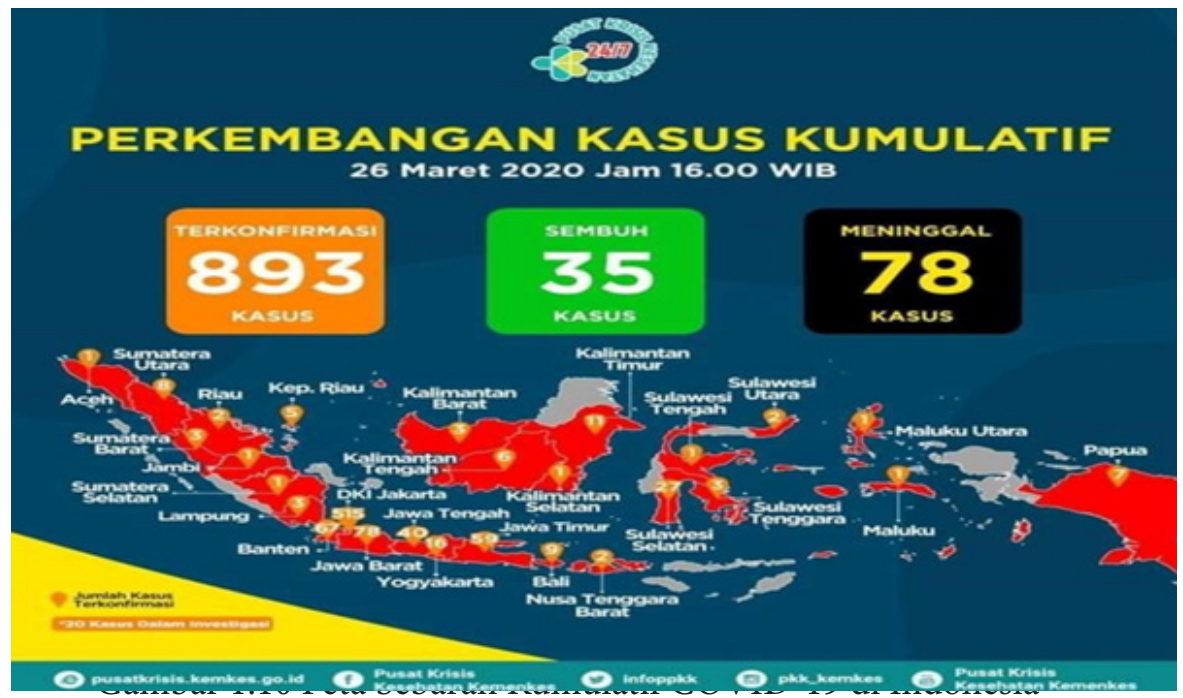

Untuk update terkini selanjutnya ada beberapa hotline dan weblink resmi untuk digunakan dalam mengikuti perkembangan Covid-19 di dalam negeri maupun luar negeri di antaranya:

18 Sumber: https://www.covid19.go.id/

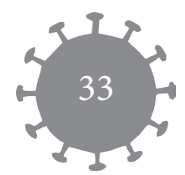


a. Tingkat Nasional

- https://infeksiemerging.kemkes.go.id/

Situs web ini berisi update jumlah kasus baik situasi global maupun situasi di Indonesia. Situasi global meliputi jumlah kasus konfirmasi, jumlah kasus meninggal, jumlah negara terjangkit dan jumlah negara dengan transmisi lokal. Selain itu juga terdapat jumlah kasus konfirmasi maupun kasus meninggal di Tiongkok. Situasi di Indonesia meliputi jumlah spesimen yang diterima, kasus negatif, kasus konfirmasi, kasus meninggal, kasus sembuh, dan dalam perawatan serta wilayah transmisi lokal.

- http://sehatnegeriku.kemkes.go.id/

Situs web ini berisi rilis tentang Covid-19 maupun pemberitaan terkait Covid-19.

- https://promkes.go.id

Situs ini berisi kumpulan Flyer Pencegahan Covid-19, kumpulan video terkait Covid-19 dan kumpulan publikasi Medsos Covid-19.

- https://wa.me/6281133399000

Merupakan aplikasi WhatsApp (WA) dari Pusat Informasi Covid-19 dari Kementerian Komunikasi dan Informasi RI. Anda akan mendapatkan balasan 
secara otomatis dengan mengetik kata "halo atau selamat malam". Informasi yang diberikan antara lain kabar Covid-19 terkini di Indonesia, apakah Covid-19, gejala Covid-19, bagaimana cara melindungi diri dan orang lain, perlukah masker, dan rumah sakit yang menjadi rujukan Covid-19.

b. Tingkat internasional

- https://www.who.int/emergencies/diseases/novelcoronavirus-2019

Pada situs web ini terdapat data jumlah kasus konfirmasi dan meninggal secara global (seluruh dunia) dan jumlah negara terjangkit beserta sebarannya yang bisa dilihat pada dashboard.

- http://bit.ly/who-covid19-whatsapp

Merupakan WhatsApp WHO tentang Covid-19. Informasi yang diperoleh pada WhatsApp ini antara lain jumlah kasus Covid-19 terkini, bagaimana melindungi diri, mitos, saran perjalanan, dan lainlain.

Selain Situs web di atas beberapa provinsi di Indonesia juga memiliki informasi resmi mengenai Covid-19 di antaranya: Jakarta tanggap Covid-19 pada situs web: corona. jakarta.go.id. Situs web ini memberikan informasi mengenai, 
jumlah orang dalam pemantauan (ODP) dan pasien dalam pengawasan (PDP) di Jakarta serta memuat jumlah kasus konfirmasi secara nasional baik yang dirawat, sembuh maupun meninggal. Selain itu, website Provinsi Jawa Barat yaitu https://pikobar.jabarprov.go.id/ memberikan informasi jumlah kasus Covid-19 berupa kasus positif, meninggal, dan sembuh di Jawa Barat maupun di Indonesia serta jumlah ODP dan PDP. Informasi Selain itu juga memberikan informasi nama-nama rumah sakit rujukan Covid-19, hotline masing-masing kabupaten, self asessment dan halhal yang berkaitan dengan Covid-19 secara lengkap.

Dari berbagai informasi Covid-19 melalui media online, Pemerintah Indonesia mengeluarkan informasi satu pintu yang di-launching 19 Maret 2020 untuk mereduksi kesimpangsiuran berita tentang penyebaran virus corona yaitu https://www.covid19.go.id/. Situs web ini memuat situasi Covid-19 dan data sebarannya terkini dalam lingkup global maupun nasional. 